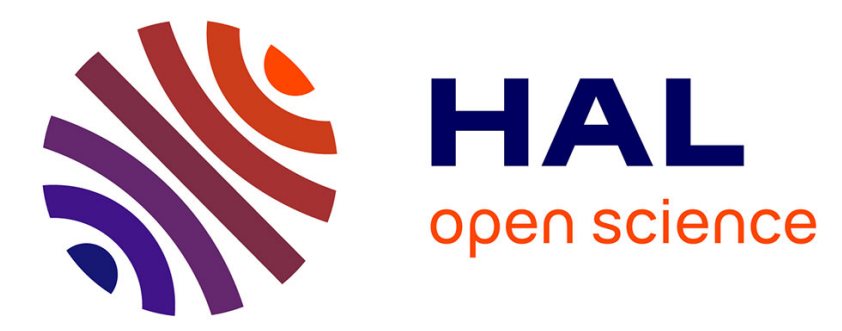

\title{
Regulation of voluntary feed intake in juvenile rainbow trout fed by hand or by self-feeders with diets containing two different protein/energy ratios
}

\author{
Thierry Boujard, Françoise Médale
}

\section{To cite this version:}

Thierry Boujard, Françoise Médale. Regulation of voluntary feed intake in juvenile rainbow trout fed by hand or by self-feeders with diets containing two different protein/energy ratios. Aquatic Living Resources, 1994, 7, pp.211-215. hal-02700545

\section{HAL Id: hal-02700545 \\ https://hal.inrae.fr/hal-02700545}

Submitted on 1 Jun 2020

HAL is a multi-disciplinary open access archive for the deposit and dissemination of scientific research documents, whether they are published or not. The documents may come from teaching and research institutions in France or abroad, or from public or private research centers.
L'archive ouverte pluridisciplinaire HAL, est destinée au dépôt et à la diffusion de documents scientifiques de niveau recherche, publiés ou non, émanant des établissements d'enseignement et de recherche français ou étrangers, des laboratoires publics ou privés. 


\title{
Regulation of voluntary feed intake in juvenile rainbow trout fed by hand or by self-feeders with diets containing two different protein/energy ratios
}

\author{
Thierry Boujard and Françoise Médale \\ INRA, Station d'Hydrobiologie, Laboratoire de Nutrition des Poissons, B.P. 3, 64310 Saint-Pée-sur-Nivelle, France. \\ Received January 6, 1994; accepted March 25, 1994.
}

\begin{abstract}
The effect of increasing non-protein energy level in a $40 \%$ protein diet on the voluntary feed intake (VFI) was investigated in juvenile rainbow trout (Oncorhynchus mykiss). Fish were fed to satiety using two different methods, hand feeding or time restricted self-feeding. Regardiess of the feeding methods, the VFI and the feed: gain ratio was always significantly higher for the fish fed the low energy diet than for those fed the high energy diet. In addition, no effect of the diet on the specific growth rate could be detected. It is concluded that fish were able to regulate with a great accuracy their feed intake when fed either by hand or by self-feeders. This regulation was precise enough to satisfy their energy needs and led fish fed the two different experimental diets to reach identical growth performance, regardless of the feeding technique.
\end{abstract}

Boujard T., F. Médale. Aquat. Living Resour., 1994, 7, 211-215.

Keywords : Food conversion, feeding behaviour, feed efficiency nutritive value, rainbow trout.

Effet du rapport protéinelénergie sur l'ingéré volontaire chez la truite arc-en-ciel nourrie manuellement ou à l'aide de distributeurs d'aliments à la demande.

Résumé

Nous avons étudié l'effet d'une augmentation de l'énergie non-protéique dans un aliment contenant $40 \%$ de protéines sur le taux d'ingestion volontaire chez la truite arc-en-ciel (Oncorhynchus mykiss) immature. Les poissons étaient nourris à satiété à la main ou à l'aide de distributeurs d'aliments à la demande. La quantité d'aliments ingérés et l'indice de consommation étaient systématiquement plus élevés chez les animaux nourris avec l'aliment contenant le moins d'énergie, indépendamment de la méthode d'alimentation. De plus, aucun effet de l'aliment sur le taux de croissance n'a été détecté. Nous concluons que les poissons ont été capables de réguler leur consommation d'aliment avec une grande précision. Cette régulation a été suffisamment précise pour correspondre à leurs besoins en énergie et, a permis aux poissons nourris avec deux aliments différents d'obtenir exactement les mêmes performances de croissance, quel que soit la méthode d'alimentation utilisée.

Mots-clés : Nutrition, comportement alimentaire, énergie, truite arc-en-ciel.

\section{INTRODUCTION}

Several works have shown that increasing the dietary fat or digestible carbohydrate levels leads to a protein-sparing effect. Based on these results, commercial feed tend to be enriched with non-protein source of energy, but protein content is not lowered.
Because fish eat primarily to cover their energy needs (Kaushik and Luquet, 1984), one might suppose that voluntary feed intake (VFI) is affected by such high energy diets.

The present work was undertaken to evaluate the effect of increasing non-protein energy level 
in a $40 \%$ protein diet on the VFI. For this purpose, two experiments with juvenile rainbow trout (Oncorhynchus mykiss) fed to satiety twice a day were performed, using two different feeding methods, hand feeding or time restricted self-feeding. In addition, and because several authors suggested that a short period of fasting induces a compensatory growth response, that could be due to a momentary hyperphagia, a third experiment was performed with hand fed fish after one week of starvation.

\section{MATERIAL AND METHODS}

Two experimental diets, designated as HE (high energy) and LE (low energy) diets, were formulated to contain a constant protein level and different proportions of starch and fish oil. After pelleting, an aliquot of each diet was sampled for analyses. Digestibility trial was performed with fish fed twice a day, the experimental diets containing $1 \%$ of chromic oxide as an inert tracer. Feces were collected over a 15-day, period using a continuous automatic feces collector (Choubert et al., 1982). Feed samples and feces were analysed following the usual procedures: dry matter $\left(110^{\circ} \mathrm{C}\right.$ for 24 hours), crude protein (Kjeldahl, total nitrogen $\times 6.25)$ after acid digestion, lipid extraction by petroleum ether in a Soxhlet apparatus after acid hydrolysis, energy using a Gallenkamp adiabatic calorimeter. The digestibility of the dietary nutrients were calculated as outlined by Kim and Kaushik (1992). Informations concerning the ingredients, the chemical composition and the apparent digestibility coefficients of the experimental diets are summarized in table 1.

Rainbow trout originating from the same parental stock and previously adapted to a commercial diet (Trouw, France, containing 54\% of crude protein and $21 \mathrm{~kJ}$ gross energy/g dry matter), were obtained from INRA experimental Fish Farm (Donzacq, Landes, France). At the beginning of the trials, after one day of fasting, fish (initial body weight [BW] between 25 and $30 \mathrm{~g}$ ) were randomly alloted into two replicates per diet (50 trout each) in experiment $A$, four replicates per diet ( 22 trout each) in experiment $B$, and five replicates per diet (20 trout each) in experiment $C$. In the three experiments, temperature was maintained between 16 and $17.5^{\circ} \mathrm{C}$. The overall mortality was lower than $5 \%$ in experiment $\mathrm{A}$, and only one fish died in experiments $B$ and $C$.

In experiment $\mathrm{A}$, fish were maintained in 3001 flow-through tanks at the INRA experimental farm (initial stocking density $5 \mathrm{~kg} / \mathrm{m}^{3}$, natural photoperiod, January-March) for 8 weeks and fed to satiety by hand twice a day, six days per weeks, at 9:00 h and 16:00 h. Feed intake was recorded weekly.

In experiment $\mathrm{B}$, fish were maintained in $100 \mathrm{l}$ tanks supplied with recirculated water, for 6 weeks (initial stocking density $6 \mathrm{~kg} / \mathrm{m}^{3}$ ). Artificial photoperiod was
Table 1. - Ingredients, chemical composition and apparent digestibility coefficients (ADC) of the experimental diets HE (high energy) and LE (low energy).

\begin{tabular}{|c|c|c|}
\hline Ingredients $(\mathrm{g} / \mathrm{kg})$ & $\mathrm{HE}$ & $\mathrm{LE}$ \\
\hline Norwegian Herring meal ${ }^{1}$ & 572 & 572 \\
\hline Gelatinized starch (wheat) & 202 & 136 \\
\hline Crude starch (wheat) & 0 & 237 \\
\hline Fish oil (Sopropeche, France) & 186 & 15 \\
\hline Mineral mix & 10 & 10 \\
\hline Vitamin mix & 10 & 10 \\
\hline $\mathrm{Na-a}$ ginate & 10 & 10 \\
\hline Chemical composition & $\mathrm{HE}$ & LE \\
\hline Dry matter $(\%)$ & 95.0 & 93.8 \\
\hline Protein $(\mathrm{N} \times 6.25)\left(\% \mathrm{DM}^{2}\right)$ & 40.6 & 40.5 \\
\hline Fat $\left(\% \mathrm{DM}^{2}\right)$ & 22.9 & 6.6 \\
\hline Gross energy $\left(\mathrm{kJ} / \mathrm{g} \mathrm{DM}^{2}\right)$ & 22.6 & 18.9 \\
\hline$A D C$ values $(\%)$ & $\mathrm{HE}$ & LE \\
\hline Dry matter & 82.5 & 76.6 \\
\hline Protein & 91.3 & 90.5 \\
\hline Fat & 92.0 & 92.5 \\
\hline Energy & 90.3 & 85.3 \\
\hline Digestible energy $\left(\mathrm{kJ} / \mathrm{g} \mathrm{DM}{ }^{2}\right)$ & 20.4 & 16.2 \\
\hline Digestible protein $\left(\% \mathrm{DM}^{2}\right)$ & 37.1 & 36.7 \\
\hline \multicolumn{3}{|l|}{ Digestible protein } \\
\hline /Digestible energy ratio $(\mathrm{mg} / \mathrm{kJ})$ & 18.2 & 22.7 \\
\hline
\end{tabular}

$170 \%$ crude protein.

2 DM = Dry matter.

12L:12D (lights on at 7:00 h), and fish were fed by means of electronic self-feeders that use a magnetic detector for the feed demands, previously described in Boujard et al. (1992). The use of self-feeders was restricted to the three hours following the artificial dawn, and to the two hours that precede the artificial dusk, six days per weeks only. Feed intake was recorded weekly.

In experiment $\mathrm{C}$, fish were maintained in 501 tanks supplied with recirculated water for three weeks (initial stocking density $13 \mathrm{~kg} / \mathrm{m}^{3}$ ). Artificial photoperiod was 12L:12D (lights on at 7:00 h), and fish were fed, after one week of fasting, by hand to satiety twice a day, at 9:00 $\mathrm{h}$ and 16:00 h. Feed intake was recorded daily.

At the beginning and at the end of each trial, groups of fish were counted and weighed after one day of fasting in a pre-weighed bucket of water. The growth performance and feed intake were described using the following parameters:

- specific growth rate $(\mathrm{SGR})=100 \times(\operatorname{Ln}($ final weight) - Ln(initial weight))/days;

- feed gain ratio $(F G R)=$ feed consumption/weight gain (dry/wet);

- voluntary feed intake (VFI) $=$ feed consumption/fish weight (dry/wet);

- gross energy (GE) intake $=$ voluntary feed intake $\times \mathrm{GE}$ of the diet; 
Table 2. - Feed intake and efficiency in experiment A. Fish were fed by hand, ad libitum, twice a day, 6 days per week, for 8 weeks (mean $\pm \mathrm{SD}, \mathrm{n}=2$ ).

\begin{tabular}{|c|c|c|c|c|}
\hline & \multirow[b]{2}{*}{$\mathrm{HE}$} & \multirow[b]{2}{*}{ LE } & \multicolumn{2}{|c|}{ Test and probability } \\
\hline & & & $F$ values & $p(\text { ANOVA })^{2}$ \\
\hline $\begin{array}{l}\text { Initial weight }{ }^{1}(g) \\
\text { Final weight }{ }^{1}(g)\end{array}$ & $\begin{array}{l}28.1 \pm 0.5 \\
76.7 \pm 3.6\end{array}$ & $\begin{array}{l}29.0 \pm 0.2 \\
77.9 \pm 1.6\end{array}$ & $\begin{array}{l}2.06 \\
0.85\end{array}$ & $\begin{array}{l}\text { n.s. } \\
\text { n.s. }\end{array}$ \\
\hline $\begin{array}{l}\text { Feed gain ratio } \\
\text { Specific growth rate } \\
\text { (\% BW/day) } \\
\text { Voluntary feed intake } \\
\text { (\% BW/day) }\end{array}$ & $\begin{array}{l}1.2 \pm 0.1 \\
1.8 \pm 0.1 \\
2.1 \pm 0.1\end{array}$ & $\begin{array}{l}1.6 \pm 0.1 \\
1.8 \pm 0.1 \\
2.5 \pm 0.1\end{array}$ & $\begin{array}{r}0.20 \\
61.36\end{array}$ & $\begin{aligned} & \text { n.s } \\
< & 0.05\end{aligned}$ \\
\hline $\begin{array}{l}\text { Intake (g or } \mathrm{kJ} / \mathrm{kg} \mathrm{BW} \\
\text { Gross energy } \\
\text { Digestible energy } \\
\text { Crude protein } \\
\text { Digestible protein }\end{array}$ & $\begin{array}{l}V / d) \\
443 \pm 9 \\
400 \pm 8 \\
8.0 \pm 0.2 \\
7.2 \pm 0.1\end{array}$ & $\begin{array}{l}452 \pm 8 \\
387 \pm 7 \\
9.7 \pm 0.2 \\
8.8 \pm 0.2\end{array}$ & $\begin{array}{r}0.60 \\
1.28 \\
52.98 \\
54.30\end{array}$ & $\begin{array}{l}\text { n.s. } \\
\text { n.s. } \\
<0.05 \\
<0.05\end{array}$ \\
\hline
\end{tabular}

1 Total fish weight/number of fish.

2 n.s. = not significant at the probability level of 0.05 .

- digestible energy (DE) intake $=\mathrm{GE}$ intake $x$ apparent digestibility coefficient of the energy;

- crude protein $(\mathrm{CP})$ intake $=$ voluntary feed intake $\times \mathrm{CP}$ of the diet;

- digestible protein (DP) intake $=\mathrm{CP}$ intake $X$ apparent digestibility coefficient of the protein.

Data were analysed for normality of variance. They were log-transformed when necessary before being analysed statistically. Arc sinus transformations of percentage data were performed to achieve homogeneity of variance. Data were subsequently analyzed by ANOVA with the SAS package (SAS Inst. Inc., NC, USA). When F values indicated significance, individual means were compared using the Duncan multiple range test $(p<0.05)$.

\section{RESULTS}

The results of experiments $\mathrm{A}, \mathrm{B}$ and $\mathrm{C}$ are summarized in tables 2,3 and 4, respectively.

Regardless of the diet, no differences in VFI were detected between fish fed by hand (experiment A) or by self-feeder (experiment B) during 6 to 8 weeks, but the VFI was enhanced in experiment $C$, when fish were previously submitted to a 1-week period of fasting. The specific growth rate (SGR) was significantly higher in experiment $C$ than in experiment $A$ and B $(p<0.0001)$, and significantly higher in experiment B than in experiment A $(p<0.001)$.

Within each experiment, the VFI and the FGR was always significantly higher for the fish fed the LE diet than for those fed the HE diet. In experiment $C$, where feed intake was recorded daily, a significant effect of the diet on the VFI $(p<0.05)$ was observed right from the second day of the experiment (fig. $1 a$ ). No effect
Table 3. - Feed intake and efficiency in experiment B. Fish had time restricted access to an electronic self-feeder 5 hours per day ( 3 hours at dawn and 2 hours before dusk), 6 days per week, for 6 weeks (mean $\pm \mathrm{SD}, n=4$ ).

\begin{tabular}{|c|c|c|c|c|}
\hline & \multirow[b]{2}{*}{ HE } & \multirow[b]{2}{*}{ LE } & \multicolumn{2}{|c|}{ Test and probability } \\
\hline & & & $F$ values & $p$ (ANOVA) $^{2}$ \\
\hline Initial weight $^{1}(\mathrm{~g})$ & $26.8 \pm 0.8$ & $26.9 \pm 0.6$ & 0.35 & n.s. \\
\hline Final weight ${ }^{1}(\mathrm{~g})$ & $64.9 \pm 2.4$ & $64.0 \pm 1.5$ & 0.75 & n.s. \\
\hline \multirow{4}{*}{$\begin{array}{l}\text { Feed gain ratio } \\
\text { Specific growth rate } \\
\text { (\% BW/day) } \\
\text { Voluntary feed intake } \\
\text { (\% BW/day) }\end{array}$} & $1.1 \pm 0.1$ & $1.3 \pm 0.1$ & 6.45 & $<0.05$ \\
\hline & $2.1 \pm 0.1$ & $2.1 \pm 0.1$ & 0.68 & n.s \\
\hline & & & & \\
\hline & $2.2 \pm 0.1$ & $2.6 \pm 0.2$ & 6.16 & $<0.05$ \\
\hline \multicolumn{5}{|c|}{ Intake (g or $\mathrm{kJ} / \mathrm{kg} \mathrm{BW/d}$ ) } \\
\hline Gross energy & $465 \pm 25$ & $457 \pm 47$ & 0.06 & n.s. \\
\hline Digestible energy & $419 \pm 23$ & $392 \pm 40$ & 1.07 & n.s. \\
\hline Crude protein & $8.3 \pm 0.5$ & $9.8 \pm 1.0$ & 6.19 & $<0.05$ \\
\hline Digestible protein & $7.5 \pm 0.4$ & $8.9 \pm 0.9$ & 6.34 & $<0.05$ \\
\hline
\end{tabular}

Table 4. - Feed intake and efficiency in experiment C. After one week of starvation, fish were fed by hand, ad libitum, twice per day, 6 days per weeks, for 2 weeks (mean $\pm \mathrm{SD}, n=5$ ).

\begin{tabular}{|c|c|c|c|c|}
\hline & \multirow[b]{2}{*}{$\mathrm{HE}$} & \multirow[b]{2}{*}{ LE } & \multicolumn{2}{|c|}{ Test and probability } \\
\hline & & & $F$ values & $p(\text { ANOVA })^{2}$ \\
\hline $\begin{array}{l}\text { Initial weight }{ }^{1}(\mathrm{~g}) \\
\text { Final weight }^{1}(\mathrm{~g})\end{array}$ & $\begin{array}{l}24.5 \pm 0.7 \\
40.0 \pm 1.7\end{array}$ & $\begin{array}{l}25.1 \pm 0.7 \\
40.0 \pm 1.0\end{array}$ & $\begin{array}{l}0.92 \\
0.25\end{array}$ & $\begin{array}{l}\text { n.s. } \\
\text { n.s. }\end{array}$ \\
\hline $\begin{array}{l}\text { Feed gain ratio } \\
\text { Specific growth rate } \\
\text { (\% BW/day) } \\
\text { Voluntary feed intake } \\
\text { (\% BW/day) }\end{array}$ & $\begin{array}{l}0.9 \pm 0.1 \\
3.5 \pm 0.2 \\
3.1 \pm 0.1\end{array}$ & $\begin{array}{l}1.1 \pm 0.1 \\
3.3 \pm 0.1 \\
3.6 \pm 0.1\end{array}$ & $\begin{array}{r}68.00 \\
2.95 \\
62.24\end{array}$ & $\begin{array}{c}<0.0001 \\
\text { n.s } \\
<0.0001\end{array}$ \\
\hline $\begin{array}{l}\text { Intake (g or } \mathrm{kJ} / \mathrm{kg} \mathrm{BW} \\
\text { Gross energy } \\
\text { Digestible energy } \\
\text { Crude protein } \\
\text { Digestible protein }\end{array}$ & $\begin{array}{l}V / d) \\
659 \pm 15 \\
595 \pm 14 \\
11.8 \pm 0.3 \\
10.7 \pm 0.3\end{array}$ & $\begin{array}{l}641 \pm 21 \\
549 \pm 18 \\
13.7 \pm 0.4 \\
12.4 \pm 0.4\end{array}$ & $\begin{array}{c}1.98 \\
16.20 \\
51.54 \\
53.21\end{array}$ & $\begin{aligned} & \text { n.s. } \\
< & 0.001 \\
< & 0.0001 \\
< & 0.0001\end{aligned}$ \\
\hline
\end{tabular}

of the diet on SGR could be detected within each of the three experiments.

In the three experiments, the intake of crude (or digestible) protein was significantly lower in fish fed the HE diet than in those fed the LE diet. GE intake was not different between the dietary treatments, and the intake of DE was significantly affected by diet only in experiment $C$. However, in experiments $A$ and $B$ the $F$ values obtained by ANOVA when comparing the $\mathrm{DE}$ intake were higher than when comparing the $\mathrm{GE}$ intake. In experiment $\mathrm{C}$, a regulation of the energy intake was shown right from the second day $(f i g .1 b)$. 

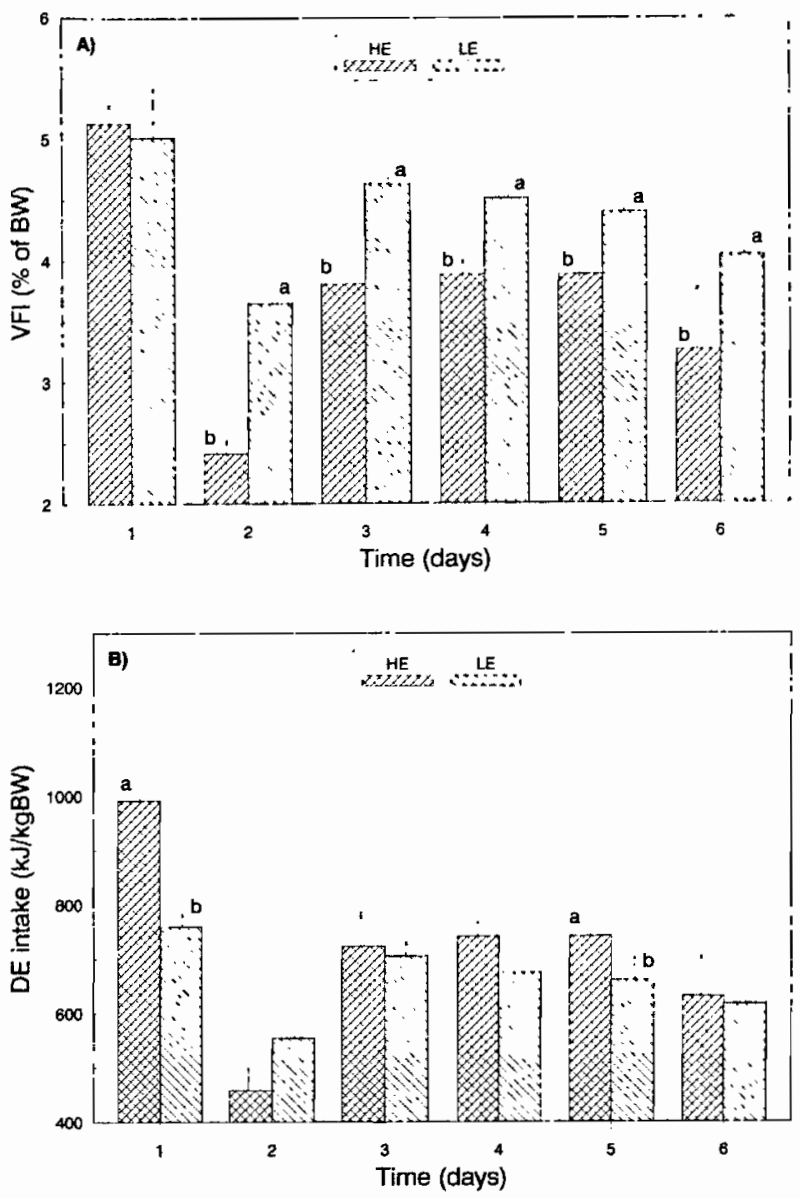

Figure 1. - Evolution in experiment $\mathrm{C}$ of $\mathrm{A}$ ) the voluntary feed intake (VFI), and B) DE intake during the first 6 days following one week of starvation, for fish fed the high energy (HE) and the low energy (LE) diets (vertical line represents one standard deviation). Vertical bars with different letters are significantly different $(p>0.05)$.

\section{DISCUSSION}

It is obvious that in these experiments, fish were able to regulate with a great accuracy their feed intake when fed either by hand or by self-feeders, in a two, six or eight weeks trial. This regulation was precise enough to satisfy their energy needs and led fish fed the two different experimental diets to reach identical growth performance, regardless of the feeding technique. These results are in accordance with the theory of VFI regulation based on energy needs (Page and Andrews, 1973), and agree with other experiments with rainbow trout fed ad libitum by hand with different feed compositions (Lee and Putnam, 1973; Takeuchi et al., 1978; Kaushik and Luquet, 1984). The beneficial effect of increasing level of dietary non protein energy was confirmed, since the SGR of fish fed the HE diet was not affected in spite of a decrease in both crude and digestible protein intake, showing the protein-sparing effect of non-protein energy sources (see Cho and Kaushik, 1990 , for references).

Because each of the three experiments were conducted in very different experimental structures and with different fish densities, inter-experimental comparisons should be made with considerable care. Nevertheless, it has to be pointed out that the lack of difference in VFI between experiments A and B, with fish fed by hand or by self-feeders, suggests that VFI is not influenced by the experimental situation, and that self-feeders can be successfully used for such studies (Anthouard and Wolf, 1988; Boujard et al., 1992; Cho, 1992).

The first day of the experiment $\mathrm{C}$, VFI reached $5 \%$ of the body weight of the fish, regardless of the diet ingested. This value probably reflects the physical limit in maximum feed intake in these experimental conditions. It also imply that regulation of feed intake on the basis of the dietary energy levels cannot be efficient right from the first day of a feeding trial. During the second day of the experiment, VFI and DE intake were lower than in any other days of the experiment. VFI and DE intake were also lower, during this second day, in fish fed the HE diet than in fish fed the LE diet. This suggests that the hyperphagia observed during the first day of the experiment is compensated right from the second day by a dramatic reduction of feed intake that seems already regulated on the basis of the dietary energy levels. This rapidity of regulation of feed intake has never been clearly demonstrated so far. Nevertheless, the rapidity of adaptation to new conditions has already been demonstrated by Kaushik (1981) and Fauconneau et al. (1983). These authors observed that after a sudden $10^{\circ} \mathrm{C}$ rise in temperature, VFI, and gastric evacuation rate was stabilized within 4 days.

The very high VFI and SGR observed in experiment $\mathrm{C}$, and the immediacy of the control of energy intake, also suggests that after a period of under-nutrition, the subsequent hyperphagia observed is limited to a maximum of energy intake, even when this "set-point" is much higher than with previously well fed fish. This result confirms those of Metcalfe and Thorpe (1992) who reported an increase in VFI of Atlantic salmon (Salmo salar) after a period of food deprivation. According to these authors, this increase in feed intake would be related to the low body lipid content of the fish. Jobling and Miglavs (1993) also suggested that the size of the lipid stores are inversely related to the VFI in Artic charr (Salvelinus alpinus).

As a conclusion, these experiments emphasize the fact that in rainbow trout, VFI is efficiently and very rapidly adjusted to the dietary energy content. The level of voluntary energy intake seems to be modulated by the nutritional state of the fish. 


\section{Acknowledgements}

The authors which to thank I. Bados, Y. Hontang, F. Terrier and F. Sandres for their technical assistance during the feeding trials, as well as S. J. Kaushik for his helpful review of the manuscript.

\section{REFERENCES}

Anthouard M., V. Wolf, 1988. A computerized surveillance method based on self-feeding measures in fish populations. Aquaculture, 71, 151-158.

Boujard T., X. Dugy, D. Genner, C. Gosset, G. Grig, 1992. Description of a modular, low cost, eater meter for the study of feeding behavior and food-preferences in fish. Physiol. Behav., 52, 1101-1106.

Cho C. Y., 1992. Feeding systems for rainbow trout and other salmonids with reference to current estimates of energy and protein requirements. Aquaculture, 100, 107123.

Cho C. Y., S. J. Kaushik, 1990. Nutritional energetics in fish: energy and protein utilization in rainbow trout (Salmo gairdneri). World Rev. Nutr. Diet., 61, 132-172.

Choubert G., J. De la Noüe, P. Luquet, 1982. Digestibility in fish: improved device for automatic collection of feces. Aquaculture, 29, 185-189.

Fauconneau B., G. Choubert, D. Blanc, J. Breque, P. Luquet, 1983. Influence of environmental temperature on flow rate of foodstuffs through the gastrointestinal tract of rainbow trout. Aquaculture, 34, 27-39.

Jobling M., I. Miglavs, 1993. The size of lipid depots - a factor contributing to the control of food intake in arctic charr, Salvelinus alpinus? J. Fish Biol., 43, 487-489.
Kaushik S. J., 1981. Influence of a rise in temperature on the nitrogen excretion of rainbow trout (Salmo gairdneri R.). Proc. World Symp. on Aquaculture in Heated effluents and recirculation systems. EIFAC Symp., Berlin, 80, 77-89.

Kaushik S. J., P. Luquet, 1984. Relationship between protein intake and voluntary energy intake as affected by body weight with an estimation of maintenance needs in rainbow trout. Z. Tierphysiol. Tierernähr. Futtermittelkd., 51, 57-69.

Kim J. D., S. J. Kaushik, 1992. Contribution of digestible energy from carbohydrates and estimation of protein/energy requirements for growth of rainbow trout (Oncorhynchus mykiss). Aquaculture, 106, 161-169.

Lee D. J., G. B. Putnam, 1973. The response of rainbow trout to varying protein/energy ratios in a test diet. $J$. Nutr., 103, 916-922.

Metcalfe N. B., J. E. Thorpe, 1992. Anorexia and defended energy levels in over-wintering juvenile salmon. J. Anim. Ecol., 61, 175-181.

Page J. W., J. W. Andrews, 1973. Interactions of dietary levels of protein and energy on channel catfish (Ictalurus punctatus). J. Nutr., 103, 1339-1346.

Takeuchi T., M. Yokoyama, T. Watanabe, C. Ogino, 1978. Optimum ratio of dietary energy to protein for rainbow trout. Bull. Jap. Soc. Scient. Fish., 44, 729-732. 